\title{
PHYTOCHEMICALS FOR HEALTHY LIVING: EXTRACTION AND USAGE
}

\author{
Priya Khareta, Mona Vashisht, Meena Bhandari, Seema Raj \\ E-Mail Id: priyakhareta99@gmail.com, monavashistha05@gmail.com, \\ meena.bhandari@krmangalam.edu.in, seema.raj@krmangalam.edu.in \\ Department of Chemistry, School of Basic and Applied Sciences, K.R. Mangalam University, Gurugram
}

\begin{abstract}
Plants are the chief source of active ingredients or chemicals which are used in pharmaceutical industry. Pharmacological activity of plants makes them useful for curing bacterial, fungal contagions and also chronic-progressive diseases like diabetes and cancer etc. The synthetic molecules prepared in the laboratories, when used as medicine for treating for different diseases produce several side effects and continuous usage of those medicines is not recommended. The search for new plant based molecules for the pharmaceutical and agrochemical manufacturing companies are continuous process that necessitates continual optimization. In this article, we present the process of extraction of phytochemicals, isolation and identification of organic compounds. Antioxidant and anticancer properties of some of the plants are also discussed.
\end{abstract}

\section{INTRODUCTION}

Phytochemicals or phytonutrients are the chemicals obtained from plants, produced through $1^{\circ}$ and $2^{\circ}$ metabolism and show biological activity. They are biologically active compounds which possess disease protective or preventive properties. Various chemicals in fruits and vegetables are not only beneficial for deterrence and management of various ailments but color, aroma and taste of food prepared by these plants is also due to their presence. Phytochemicals are mainly concentrated in colorful parts of the plants like fruits, vegetables, nuts, legumes etc. Color of blueberries, odor of broccolis, and pungent odor of garlic is attributed to presence of phytochemicals [1].They provide protection to plants from disease, infection and guard against pathogens or predators and take part in plant growth by providing beneficial nutrient to them [2].

Researchers are now heading towards to find new ways to obtain them by synthetic methods in lab [3]. Apart from providing nutrition, plants are used from centuries for preparation of medicines, dyes etc. [2]. In the process of exploring new chemicals, various methods were developed to establish the structure of compound responsible for healing properties [3]. Each phytochemical works differently and accomplish a number of purposes such as antioxidant activity, hormonal action, antibacterial effect, antimicrobial action and anticancer activity.

Till now scientists have researched about 3,000 different phytochemicals with possible health benefits. Phytochemicals extracted from plants have been used in pharmaceuticals for cancer, urinary disease, fever, cardiovascular diseases, diabetes etc. Different medicines and techniques are used for handling these diseases but they also have been shown to produce side effects on our health. Chemotherapy is given to patients so as to treat cancer but it also has been found to generate some side effects which unduly affect patient's health. So now researchers focus on the use of such drugs and medicines extracted from natural products; that would show remarkable effect on antigens of disease and would not show any side effect on healthy cell. So now, modern science has changed its path and move towards the natural products [4].

Phytochemicals produces good and positive effects on human body i.e. they strengthen our immune system, improve our digestive system and acts as antioxidant [5]. Indoles, Isothiocyanate and sulforaphane present in broccoli, allylic sulfides from onion, garlic, isoflavonoids from soybeans etc. show positive impact on human health.

Studies suggest that the food having good servings of fruits, vegetables, and whole grain provide defense against cancer, cardiovascular problems, diabetes and neurodegenerative ailment etc. Plants having favorable phytoconstituents may enhance the immunity of humans by providing natural antioxidants. Broccoli, sprouts, carrots, sweet potato, soybean etc. contain antioxidants. Dark colored fruits and vegetables have more antioxidants than other fruits and vegetables. Consumption of antioxidants can prevent or slow down the damage to cell caused by free radicals [6]. Similarly, sulfides in onion and garlic may strengthen the immune system. Anthocyanins found in grapes, blueberries and raspberries because of their dark color have anti-inflammatory and anti-tumor properties. Phytochemicals are power packed bites of plants known to be essential for health, like vitamins and minerals. Studies show that high intakes of fruits and vegetables minimize the risks of chronic diseases. Different phytochemicals present in plant exhibit different impact on the humans [7-8].

Evidence suggests that ingesting soy having isoflavones and cocoa having polyphones may decrease the possibility of cardiovascular disease by improving endothelial function by dilating blood vessels. Consumption of wide range of phytochemicals helps in lowering blood pressure, inflammation, LDL oxidation and may increase HDL cholesterol. Phytochemicals like anthocyanins, phytosterols, phenolic acids, lignans and carotenoids present in wheat, rye, oats, rice and other grains are known to have cardio protective effects.

Intake of phytochemicals may not cure the disease but consumption of these phytochemicals may help in prevention of disease or reduce the risk of disease. Further research is going on for the extraction and usage of phytochemicals in pharmaceutical industries [9].

Phytochemicals show potential to [10] -

DOI Number: https://doi.org/10.30780/specialissue-ICAASET021/022

Paper Id: IJTRS-ICAASET2021-022

pg. 131

@2017, IJTRS All Right Reserved, www.ijtrs.com 
ICAASET-2021, 20-21 May, 2021, K.R. Mangalam University, Gurugram

International Journal of Technical Research \& Science (Special Issue) ISSN No.:2454-2024 (online)

$>$ Enhance immunity

$>$ Prevent formation of carcinogenic substances in the body

$>$ Diminish infection

$>$ Avert DNA damage

$>$ Lessen impairment to cells due to oxidation.

$>$ Limit speed of formation of tumor

$>$ Triggered damaged cells to apoptosis afore they replicate

$>$ Gene expression

$>$ Activate insulin receptors

It was observed that increasing the ingestion of fruits and vegetables from fewer to 3-4 times a day may cut the danger of illness by $17 \%$ [11].

Phytochemicals have been divided into six groups depending upon their chemical structure as well as properties such as carbohydrate, lipids, phenolic, terpenoids, alkaloids and other nitrogen containing molecules etc. as explained in the figure 1 given below [3].

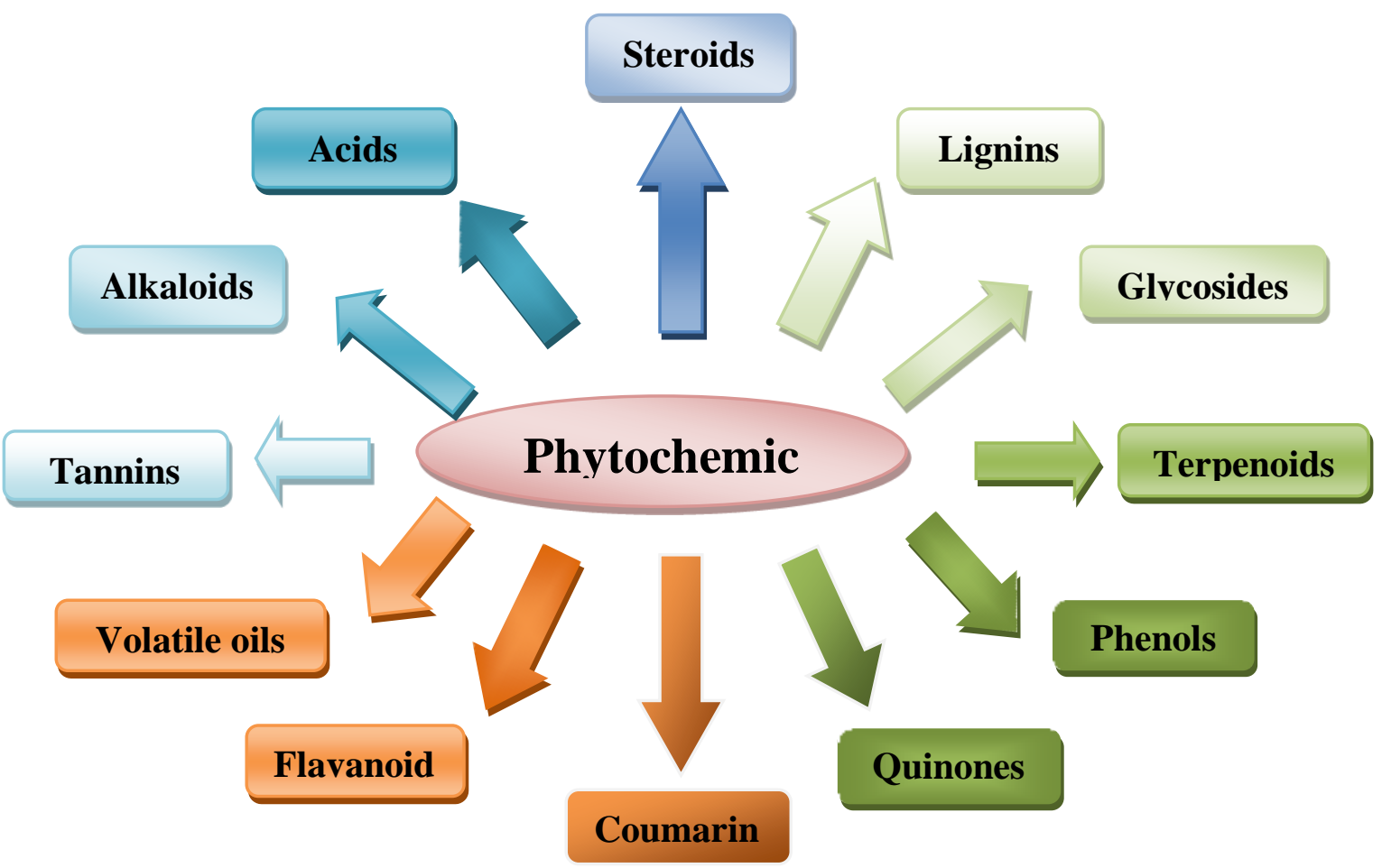

Fig. 1.1 Major group of Phytochemicals

\subsection{Need for Phytochemicals}

Phytochemicals plays an important role to lead a healthy life. In vegetables and fruits a protective layer is present which can minimize the hazard of developing prolonged diseases. Flavanoids, plant's pigments decrease oxidation, enhance the level of vitamin $\mathrm{C}$ and provide strength to the tissues. Intake of isothiocyanates through certain vegetables like broccoli, cauliflower, cabbage etc. can hinder growth of cancer cells as well as causing their death [12-14]. Carotenoids are prevalent in colored fruits and vegetables like berries, tomatoes, carrots, watermelon, etc. They exhibit antioxidant properties and protect against certain cancer like prostate. The most common dietary carotenoids are $\alpha$-carotene, $\beta$ - carotene and it will further be converted into retinol which enhances the level of vitamin A, lutein, lycopene, and zeaxathin [15-16]. Quercetin are present in apples, onions, citrus fruits, berries, red grapes, broccoli , cocoa, and tea and are useful for protecting against heart diseases and cancer [12]. Phytochemicals provide protection against cancer and cardiovascular diseases as they tend to prevent the creation of new blood vessels which is a trademark of cancer and also control nitric oxide, soothing blood vessels resulting in good blood flow [12].

Presence of certain phytochemicals in majority of foods, herbs etc. act as nutraceutical and produce remarkable influence for prevention or control of various ailments [7]. The phytochemicals may arouse immunity, decrease the rate of growth of cancer cells and avert DNA impairment to prevent diseases [16]. Phytochemicals shows antioxidant properties by reacting with free radicals [17-18]. 
ICAASET-2021, 20-21 May, 2021, K.R. Mangalam University, Gurugram

International Journal of Technical Research \& Science (Special Issue) ISSN No.:2454-2024 (online)

Broccoli, cabbage and cauliflower are known to diminish the danger of prostate, lung, breast and colon cancers [19]. Isothiocyanate and sulforaphane found in cruciferous vegetable and broccoli respectively helps in preventing cancer. Polyphenols present in tea provide defensive against diverse kinds of cancer [20].

Some medicinal plants like Bearberry, rose bay willow herb, aloe vera, tinospora cordifolia etc. have been used in pharmaceuticals because of their various disease resisting properties. T. Cordifolia has been used for fever, dyspepsia, jaundice, skin and urinary disease. Aloe Vera is used in skin related problems; possess anti-oxidant, anti-inflammatory and immune-modulatory properties. Rose bay willow herb is used as an intestinal astringent, anti-spasmodic in whooping cough and asthma and in balms to cure skin problems. Phytochemicals are also effective for treating bacterial and fungal infection. Intensity of chemical constituents decreases on processing of food in comparison to raw food. They protect plants from harmful agents such as insects and microbes. When oxidative stress increases means there is imbalance between free radicals and antioxidants.

Phytochemicals also acts as a supplement to boost immune system. It helps to arrest carcinogen forming substances, decrease the inflammation that stimulates cancer growth and helps to stabilize unstable molecules that can trigger cancer. Phytochemicals also help in hormone regulation. They significantly reduce the risk of cancers by stopping tumor cell propagation, modification of carcinogen and tumor metabolism, initiation of carcinogen detoxification and many more [21].

\section{METABOLISM OF PHYTOCHEMICALS}

Metabolism is a type of chemical reactions in which complex substances are breakdown into simpler one, or to degrade complex into simpler one (Figure 2). Plants (autotrophs) have two metabolism namely primary metabolism and secondary metabolism which leads to the production of phytochemicals [2].

$1^{\circ}$ is present in all living beings and is necessary for the functioning of various plants function like photosynthesis, respiratory processes etc. $2^{\circ}$ metabolites also called natural products or by-products of plants which occur in superior plants. Superior plants are those that possess flowers and have seeds. The reproductive organs of these plants are visible and hence are known by the name spermatophytes. The reproductive mechanisms of these plants are different from the inferior one [2].

$2^{\circ}$ metabolites possess biological properties showing applications in Medications, pesticides, fungicide, cologne and colourant. They also provide defense in opposition to predators, pathogens or ecological stress while others help in reproductive mechanism of plants by attracting of insects for pollination.

\section{Plant Metabolites}

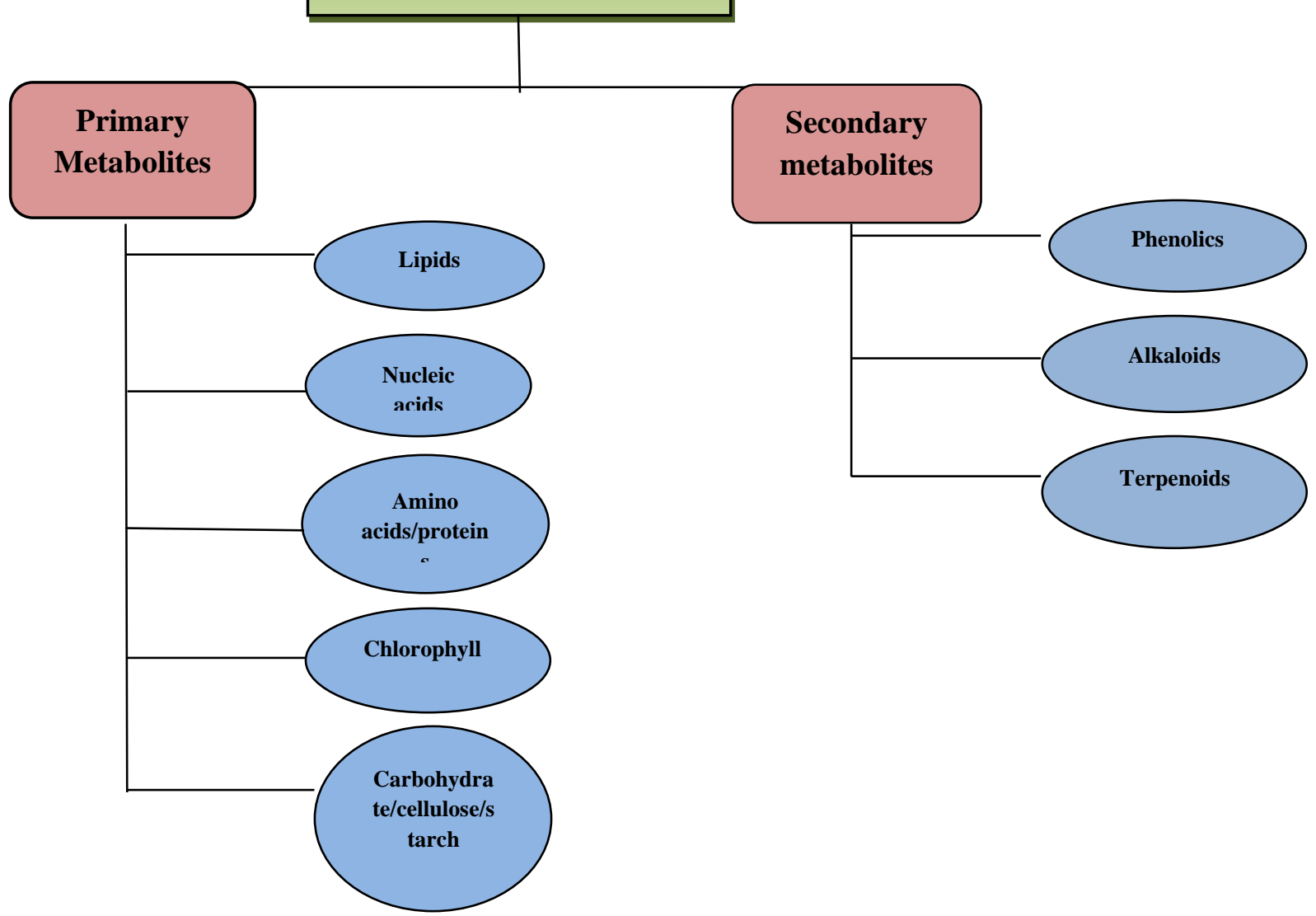

Fig. 2.1 Classification of plant metabolites

DOI Number: https://doi.org/10.30780/specialissue-ICAASET021/022

Paper Id: IJTRS-ICAASET2021-022

pg. 133

@2017, IJTRS All Right Reserved, www.ijtrs.com 
ICAASET-2021, 20-21 May, 2021, K.R. Mangalam University, Gurugram

International Journal of Technical Research \& Science (Special Issue) ISSN No.:2454-2024 (online)

\section{METHOD OF EXTRACTION, SEPARATION AND IDENTIFICATION OF ORGANIC COMPOUNDS}

Extraction is a significant process to study the medicinal therapeutic plants/herbs. Extraction simply means separating out each phytochemicals from a mixture one by one and clarifying each one of them by physical or chemical methods. It is obligatory to separate the active constituent of the plant for identifying its chemical structure [22].

Basic operation included in the extraction process is:-

$>$ Pre-washing

$>$ Cutting/slicing of parts of plant or freeze desiccating

$>$ Crushing to get a homogeneous material

The targeted compound (i.e. Phytochemical) to be extracted may be polar, non-polar and heat labile [23] and different extraction methods are used. Botanical excerpts are developed by maceration or percolation of living/dried parts of the plants in aqueous or organic solvents. Various methods are used for extraction purpose these are sonification, refluxig, extraction through Soxhlet/Solvent etc. are generally used. With the development of science modern techniques are used for the extraction as they possess certain advantages over the classical methods. While extracting out phytochemicals with classical method; the compound obtained upon extraction is in very minor/less amount and it becomes difficult to study the structural properties so in place of these modern techniques are used. Because in classical method various reactions are there such as chemical degradation, derivative synthesis which is difficult to carry out with minute amount of compound; while in modern techniques they work with a little amount of sample as much as possible for structure identification [24].

The advantages of modern methods over traditional one are as follows-

$>$ There is reduction in amount of solvent consumed.

$>$ Additional sample clean-up is not required.

$>$ Congregation stages beforehand chromatographic investigation

$>$ Enhancement in separation, development, regulation and refinement of process.

$>$ Easy to operate [25].

\subsection{Solvent-Extraction Methods}

It is the most basic technique. The purpose of this method is to select an appropriate solvent to separate the specific (Targeted) phytochemicals. It can be classified as cold or hot extraction depending on whether we provide heat or not. Selection of solvent is based upon "like dissolves like" principle. Appropriate polarity solvent to be used i.e. polarity of solvent and the solute (i.e. the compound to be extracted) should be same. A solvent of same polarity as that of solute will dissolve the solute completely [26]. For the extraction of hydrophobic or lipophilic component of plants non polar solvents are used. Oils, fats, chlorophyll, lactones and alkaloids are extracted with these non-polar solvents.

This method is specially used for the extraction of phenolic compounds. Solvents of appropriate polarity as that of solute are used. Many solvents successively can be made use of to extract all phytochemicals present in them without wasting a little part of it [27].

Plant compounds like terpenoids and steroids possess low polarity i.e. hydrophobic in nature and dissolve in nonpolar solvents like chloroform, ether etc. while other constituents such as carbohydrates; amino acids are highly polar, therefore polar solvents like water, aqueous ethanol etc. are used. The most popular solvents used are water, methanol, acid water and acetone.

\subsection{Microwave - Assisted Extraction (MAE)}

Researchers have been working hard to find out a technique to extract out the phytochemicals in which there is no loss of bioactive compounds and less time is required; after researching a lot they come to microwave-assisted extraction, and it seems to be a good technique from every point of view i.e. reduction in loss of bioactive compounds, less time consumption, easy to operate etc. Maximum temperature for extracting out phenols effectually is $170{ }^{\circ} \mathrm{C}$ and increasing the temperature beyond this limit, results in the opposite I.e.in the reduction of the extracted yield.

This method uses microwave radiations to separate the active components of plants. This method combines both microwave and traditional solvent extraction. Microwaves have electromagnetic radiation occurring between $300 \mathrm{MHz}$ to $300 \mathrm{GHz}$ [27]. The concept used behind this method is that it heated up that part of object that can absorb EMR and convert them to heat. Instrument used in microwave assisted extraction has a frequency of $2450 \mathrm{MHz}$ which corresponds to energy of 600-700 Watts.

Some factors that can increase the efficiency of microwave radiations are-

$>$ Extraction temperature

$>$ Extraction time

$>$ Solvent Constitution [28]

$>$ There are many advantages of MAE over conventional method which are as follows:-

$>$ Lower solvent Constitution

DOI Number: https://doi.org/10.30780/specialissue-ICAASET021/022

Paper Id: IJTRS-ICAASET2021-022

@2017, IJTRS All Right Reserved, www.ijtrs.com

pg. 134 
ICAASET-2021, 20-21 May, 2021, K.R. Mangalam University, Gurugram

International Journal of Technical Research \& Science (Special Issue) ISSN No.:2454-2024 (online)

$>$ Smaller extraction time

$>$ Higher delicacy towards targeted molecules [29]

$>$ Fast result

MAE is helpful in extracting out large amount of antioxidant activity and phenolic content phytochemicals compared to other method conventional method like solvent extraction.

\subsection{Sonication}

It is also a solvent extraction method assisted by ultrasound to extract bioactive compounds from plants. This method is simple and it is also cost- effective technology that can be used for removal of phytochemicals on both large and small scale. This method involves use of ultrasound ranging from $20 \mathrm{KHz}$ to $2000 \mathrm{Khz}$.Use of ultrasonic radiation in the extraction process is to increase the penetrable power of cell walls and produce cavitation. This method can be explained as follow i.e. When the ultrasonic vibration is passed through the medium then it gets dispersed, and numerous tiny cavities are formed in the medium, due to these tiny cavities a force of upto $1000 \mathrm{~atm}$ is formed and also the temperature of the system raised upto $1000^{\circ} \mathrm{C}$; the combination of the temperature and the pressure causes the cell wall to rupture and the solvent penetrate into this cells; and dissolves all the active ingredients into itself. When extraction of bioactive components is done using UAE [30], then there is rise in antioxidant activity from $187.13 \mathrm{umol} \mathrm{TEg}^{-1} \mathrm{DM}$ to $308 \mathrm{umol} \mathrm{TEg}-1 \mathrm{DM}$ as compared to other method.

Various experiments were conducted out to confirm that UASE was an effective extraction process as compared to other techniques. For ex- Cho et al. when separating out Resveratrol from grapes, another researcher Barbero et al. suggest the utilization of UASE in extraction of Capsaicinoids from hot pepper [31] show good result and also it is seen that when extracting out phenolic compounds from strawberries there is reduction in extraction time when using Ultra sonic assisted extraction (UAE) is better as compared to other techniques such as Solid-liquid, Subcritical water and MAE. Hence by all the experiments conducted out till now proved UAE as the most effective method.

Separation of phenolic compounds has increased from the past few years as it required less solvent and is energy efficient during the extraction [32].

\subsubsection{Advantages of Ultrasonic-Assisted Extraction}

$>$ Uses a low working temp. through depuration, maintain a high extract yield

$>$ In UAE the operation time was reduced by using the ultrasonic bath and probe system.

$>$ Capable of reducing the degradation of phenolic.[30]

$>$ Decrease in separation time and solvent consumption; improve the extraction efficiency

$>$ Uses the concept of Green technology

\subsubsection{Disadvantage of Ultrasonic-Assisted Extraction}

In spite of various advantages there are some disadvantages of UAE too. These are as follows: -

$>$ If ultrasonic radiation of more than $20 \mathrm{KHz}$ is used, then they may alter the active ingredients of plants and favors the formation of free radical.

\subsection{Supercritical Fluid Extraction (SFE)}

It is an extraction process which involves supercritical fluid (SF) for the extraction of active ingredients from plant. It uses supercritical fluid also known as murky (Dense) gas; is a matter that share characteristics of both gas and liquid at its critical point. SF behaves more like a gas as it has low viscosity like gas and heavy like a liquid. In supercritical state, the super crescent is contacted with plant tissues. Super crescent can selectively remove the components of varying polarities, B.P. and molecular weight successively and this technique is called as SFE method. In SFE method cylindrical vessels are used, and is carried out at high pressure in batch or continuous manners. SF has large diffusion rate and is able to dissolve many compounds [25]. There are a lot of materials that can be used as supercritical fluid some of them are ammonia, benzene, dichloro-difluoro methane, heptane and many but the among them the most widely used is $\mathrm{CO}_{2}$. Extraction carried out with $\mathrm{CO}_{2}$ are called $\mathrm{SC}-\mathrm{CO}_{2}$ extraction [33]. They are excellent solvents for extraction of non-polar analytes but they have poor solubility in polar compounds. For the extraction of polar analytesentrainer are added to increase their solubility.

SFE has achieved great success in field of medication, synthetic, food and environmental management. It has been used in removal of alkaloids, volatile essential oils and caffeine etc. [34].

\subsubsection{Advantages of $\mathrm{CO} 2$ When Used As Supercritical Fluid}

$>$ Easily accessible at low price and has less toxicity.

$>$ Chemical stability

$>$ Odorless

$>$ Non-flammable

3.4.2 Advantages of Supercritical Fluid Extraction Method: -

$>$ Can be carrying out at room temperature.

$>$ All bioactive components of plants can be obtained. 
ICAASET-2021, 20-21 May, 2021, K.R. Mangalam University, Gurugram

International Journal of Technical Research \& Science (Special Issue) ISSN No.:2454-2024 (online)

$>$ No residual organic solvent left.

$>$ Product obtained has high clarity and high yield or amount

$>$ Simple to operate and is energy efficient

\section{IDENTIFICATION OF STRUCTURE OF BIOACTIVE MOLECULES USING SPECTRAL ANALYSIS}

After the separation of bioactive compounds from plant, the purification and identification of the structure of compound is must. To determine the structure of molecules, various spectroscopic techniques can be used for example: Visible, Infrared, NMR and Mass spectroscopy (Figure 2).

The main concept behind using spectroscopy is that when electromagnetic radiations were passed through the sample, some of light is absorbed. So by measuring the amount of absorbed light the spectrum can be drawn. Each spectrum is specific to certain bonds. By spectra obtained we can easily recognize the structure of molecules present.

\section{METHOD OF ISOLATION}

Plants extract usually contain mixture of polar and non-polar phytochemicals so their identification and characterization is not simple rather it's little bit complicated. For the purification and isolation of phytochemicals from the mixture requires several chromatographic techniques and other methods are used. Silica, alumina, cellulose and polyamide are best suited as mobile phase for separating the phytochemicals. Solvents of increasing polarity are used I.e. if we increase the polarity using multiple solvents then it could help us in the separation of individual phytochemicals.

Thin layer chromatography, sephadex chromatography, flash chromatography and high performance liquid chromatography are employed for separation. Development of new and modern techniques like droplet counter current chromatography (DCCC), HSCCC (high speed counter current chromatography) etc. speed up the process of purification and isolation. Immunoassays, phytochemical screening assay, Fourier Transform IR Spectroscopy are also used for the sequestration of bioactive compounds from the mixture [23]. From the pure compound obtained from isolation the shape, composition and physiological activity of compound is determined.

\subsection{Thin layer chromatography (TLC)}

It is one of easiest, rapid and cost - effective chromatographic method employed to separate mixture. It is a kind of adsorption chromatography. It gives a rapid answer to researcher to know as if the mixture is consisting of how many components.

As we all know that different analytes have different migration rate and rise up with different speed and finally the mixture is separated [35].

TLC also helps in finding the identification of compound in a mixture by collating the observed Rf value of compound with the familiar one in order to analyze the spots the TLC plate is sprayed with spraying of phytochemical screening reagents, or by observing the plate under UV light. TLC is also used for validation of pureness and identification of isolated molecules.

The separation in TLC is based on interlinkage between thin layers of absorbent affix on the plate. It is mostly used for the segregation of low molecular weight compound. The main advantage of TLC is that these techniques are versatile, speedy and sensitive.

\subsection{TLC- Bioautographic methods}

This technique is used to find the antimicrobial activity of botanical extracts. Previously autographic techniques use the inhibited growth of microorganisms to detect the location of antimicrobial components. This is the most effective method for the detection of antimicrobial compound [36].

Bio- autography identifies the position of antimicrobial components present in the extract on chromatogram by using three approaches. These are as follows:

$>$ Direct bio- autography- here the micro-organisms are allowed to grow straight on TLC plate and the place which remains free from microbial growth contains the antimicrobial components of the extract.

$>$ Contact- bio- autography- In this method antimicrobial components are moved from the TLC plate to inoculated agar plate through head on contact and their growth is being noticed.

$>$ Agar-overlay bio- autography- as indicated by the name on the TLC plate agar medium is directly applied on it and growth is monitored as in the previous method [37].

Among the three methods discussed above agar overlay method is good as they uses a little amount of solvent as compared to other diffusion method. It has also a disadvantage that it has highly delicate and it's only used to noticed micro-organisms growth . 
ICAASET-2021, 20-21 May, 2021, K.R. Mangalam University, Gurugram

International Journal of Technical Research \& Science (Special Issue) ISSN No.:2454-2024 (online)

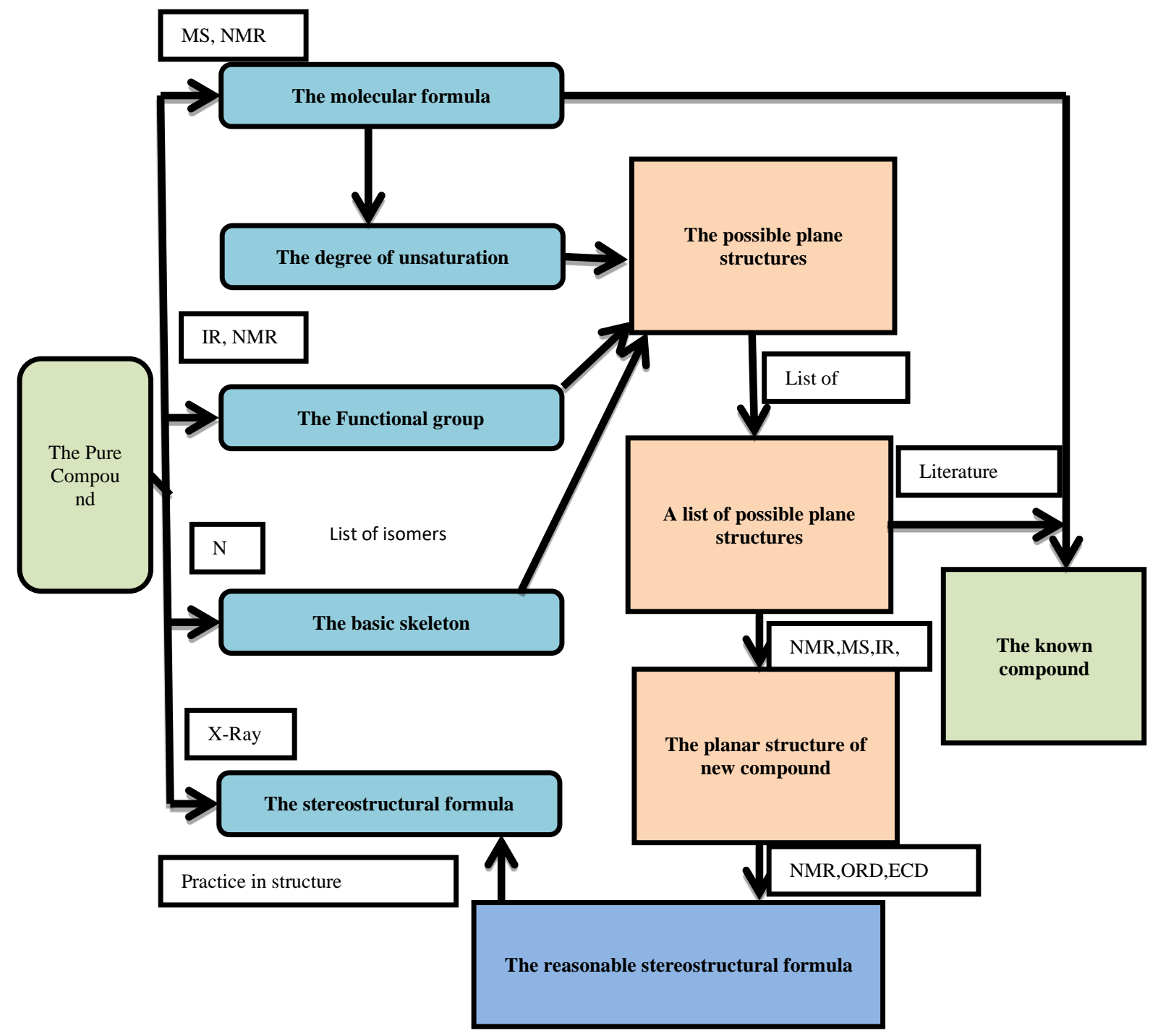

Fig. 5.1 Flow Diagram for studying the structures of phytochemicals

\subsection{HPLC (High performance liquid chromatography)}

It is a simplest, easy, adaptable and common method for segregation of natural compounds. HPLC play an important role in segregation, comparative, recognitionn and measurable study of plant chemical constituents. Objective of HPLC is to isolate, purify and collect the target compounds. Nowadays this technique is attracting researchers towards itself due to its versatility and easiest mode of working. The biologically active components is present in a minute amount and HPLC is best fitted for the separation of these active ingredients from plant extracts because of its high resolving power, rapid processing on the mixture to separate them into individual phytochemicals. It works on the principle that different compounds present in a mixture has different migration rate w.r.t mobile phase. The detectors generally used in HPLC are - ultraviolet detector and differential refractive index detectors. The ultrasonic detectors use ultraviolet radiation and cannot detect samples which do not absorb UV light whereas the differential R.I. detectors are sensitive to changes in temperature [38].

There are several advantages of HPLC some are as follows:-

$>$ High resolving power and rapid processing

$>$ High regulation, high rate and accuracy

$>$ Automatic

$>$ Both volatile and non- volatile substances can be analyzed.

\subsection{Phytochemical Screening Assay}

It is a easiest, rapid and cost - effective method that helps in recognition of different types of phytochemicals [23] present in the mixture. It is more or less similar to salt analysis in which different tests are performed for the identification of each phytochemical. After obtaining the crude extract phytochemical screening may be performed on it, to know how many different phytochemicals are present in the mixture extract.

Below given Table 1 gives different tests for each phytochemicals: -

Table-5.1 phytochemical qualitative analysis

DOI Number: https://doi.org/10.30780/specialissue-ICAASET021/022

Paper Id: IJTRS-ICAASET2021-022

pg. 137

@2017, IJTRS All Right Reserved, www.ijtrs.com 
ICAASET-2021, 20-21 May, 2021, K.R. Mangalam University, Gurugram

International Journal of Technical Research \& Science (Special Issue) ISSN No.:2454-2024 (online)

\begin{tabular}{|c|c|c|c|}
\hline $\begin{array}{l}\text { Secondary } \\
\text { Metabolites }\end{array}$ & Name of The Test & Method & Results \\
\hline Alkaloid & $\begin{array}{l}\text { Dragendroff's Test } \\
\text { Wagner Test }\end{array}$ & $\begin{array}{l}\text { A drop of extract is placed on pre- } \\
\text { coated TLC plate and is sprayed with } \\
\text { dragendroff's reagent. } \\
\text { To } 2 \mathrm{ml} \text { of filtrate, } 1 \% \mathrm{HCl} \text { is added } \\
\text { and heated. Then to } 1 \mathrm{ml} \text { of the sol. is } \\
\text { mixed with } 1 \mathrm{ml} \text { of wagner's reagent }\end{array}$ & -brownish-red precipitate \\
\hline Anthraquinone & Borntrager's test & $\begin{array}{l}\text { To } 50 \mathrm{mg} \text { of plant extract, } 1 \mathrm{ml} \text { of } \\
10 \% \mathrm{FeCl}_{3} \text { solution and } 1 \mathrm{ml} \text { of conc. } \\
\mathrm{HCl} \text { is added. } \\
\text { After cooling the filtrate, equal } \\
\text { amount of diethyl ether is added. } \\
\text { Further ether extract is treated with } \\
\text { strong ammonia. }\end{array}$ & $\begin{array}{l}\text {-pink or deep red coloration } \\
\text { of aqueous layer }\end{array}$ \\
\hline Flavonoid & $\begin{array}{l}\text {-Shinoda test } \\
\text { - } \mathrm{NaOH} \text { test }\end{array}$ & $\begin{array}{l}\text { In } 2 \mathrm{ml} \text { of methanolic extract add a } \\
\text { piece of magnesium ribbon and } 1 \mathrm{ml} \text { of } \\
\text { conc. } \mathrm{HCl} \text {. } \\
\text { Add dil. } \mathrm{NaOH} \text { to the small amount of } \\
\text { extract and followed by addition of } \\
\text { dil. } \mathrm{HCl} \text {. }\end{array}$ & $\begin{array}{l}\text {-pink or red coloration of } \\
\text { the solution } \\
\text {-a yellow sol. with } \mathrm{NaOH} \text {, } \\
\text { turn colorless with dil. } \mathrm{HCl}\end{array}$ \\
\hline Steroid & $\begin{array}{l}\text {-Libermann- } \\
\text { Buchardst test }\end{array}$ & $\begin{array}{l}\text { To } 1 \mathrm{ml} \text { of methanolic extract is added } \\
1 \mathrm{ml} \text { of chloroform, } 2-3 \mathrm{ml} \text { of acetic } \\
\text { anhydride, } 1-2 \text { drops of conc. } \mathrm{H}_{2} \mathrm{SO}_{4} \text {. } \\
\text { To } 1 \mathrm{ml} \text { of extract, } 2 \mathrm{ml} \text { of acetic } \\
\text { anhydride and } 2 \mathrm{ml} \text { of conc. } \mathrm{H}_{2} \mathrm{SO}_{4} \text { is } \\
\text { added. }\end{array}$ & $\begin{array}{l}\text {-Dark green coloration } \\
\text {-color change to blue or } \\
\text { green }\end{array}$ \\
\hline Terpenoid & $\begin{array}{l}\text {-Salkowski test } \\
\text {-Libermann- } \\
\text { Buchardst test }\end{array}$ & $\begin{array}{l}\text { To the } 5 \mathrm{ml} \text { extract is added with } 2 \mathrm{ml} \\
\text { of chloroform and } 3 \mathrm{ml} \text { of conc. } \mathrm{H}_{2} \mathrm{SO}_{4} \text {. } \\
\text { To } 1 \mathrm{ml} \text { of methanolic extract, is added } \\
1 \mathrm{ml} \text { of } \mathrm{CHCl}_{3}, \quad 2-3 \mathrm{ml} \text { of acetic } \\
\text { anhydride, } 1-2 \text { drops of conc. } \mathrm{H}_{2} \mathrm{SO}_{4} \text {. }\end{array}$ & $\begin{array}{l}\text {-reddish brown color of } \\
\text { interface } \\
\text {-pink or red coloration }\end{array}$ \\
\hline Volatile Oil & & $\begin{array}{l}2 \mathrm{ml} \text { extract is mixed with } 0.1 \mathrm{ml} \text { of dil. } \\
\mathrm{NaOH} \text { and small quantity of dil. } \mathrm{HCl} \\
\text { is added with shaking. }\end{array}$ & $\begin{array}{l}\text {-formation of white } \\
\text { precipitate }\end{array}$ \\
\hline Tannins & -Bromine Water & $\begin{array}{l}\text { Mix } 10 \mathrm{ml} \text { of bromine water with } \\
0.5 \mathrm{gm} \text { of aqueous extract. }\end{array}$ & $\begin{array}{l}\text {-discoloration of bromine } \\
\text { water. }\end{array}$ \\
\hline Phenol & -Phenol test & $\begin{array}{l}\text { Add a drop of Phoshomolybdic } \\
\text { reagent to the extract spotted on filter } \\
\text { paper and expose to ammonia vapors. }\end{array}$ & -blue coloration of the spot. \\
\hline
\end{tabular}

\section{Phytochemicals as antioxidant}

Antioxidants are responsible for elimination of free radical and helps to stop different alterations occurring in body i.e. DNA transformation to cell loss [39]. Phytochemicals having antioxidant property will reduce oxidative stress thus decreasing probability of developing cancer.

The human body has its own antioxidant mechanism i.e. antioxidant enzymes to decrease the extreme levels of free radicals. When oxidative stress increases which means there is imbalance between free radicals and antioxidants which may result into cardiovascular diseases, diabetes, cancer etc. [40]. Vegetables, fruits, grains has protective and this protective layer is a phytochemical which is very useful for a healthy body. Antioxidant can work in a synergistic manner to eliminate free radicals. Generation of extremely reactive oxygen species (ROS) takes place in cellular activities like mitochondrial respiratory chain, phagocytosis, arachidonic and metabolism, and fertilization. Free radical reactions are chain reactions which consist of initiation, propagation and termination steps. An antioxidant terminates the chain by reacting with free radical [41-43]. Antioxidants are able to turn ROS into stable, harmless molecules. They are also used in pharmaceutical, food, cosmetics, and chemical industries as preservatives [44].

There are many diseases which are caused by free radicals such as visual disorders like cataract and age related muscular degeneration, neurological diseases e.g., parkinson's diseases, digestive system diseases (inflammatory bowel disease, ulcers, colitis) and many more [45] occur when natural antioxidants present the body are not enough to fight extreme generation of reactive oxygen species.

DOI Number: https://doi.org/10.30780/specialissue-ICAASET021/022

Paper Id: IJTRS-ICAASET2021-022

pg. 138

@2017, IJTRS All Right Reserved, www.ijtrs.com 
ICAASET-2021, 20-21 May, 2021, K.R. Mangalam University, Gurugram

International Journal of Technical Research \& Science (Special Issue) ISSN No.:2454-2024 (online)

Carotenoids are accountable for yellow, orange and red color in plants. For example $\beta$-carotene, lycopene(found in tomatoes, pink and red grapefruit, colored guava, pomegranate etc.), lutein (found in collards, spinach, corn, citrus), capsaicin(present in hot red peppers, cumin, turmeric, tomato, corn, coriander, peppers and nuts), fruits and vegetables are chief sources of carotenoids and acts as antioxidants [16] and prevent chronic diseases. High concentration of carotenoids are present in carrots, orange, watermelon, sweet potatoes, green leafy vegetables kale, papaya, mangoes. Beta carotene deactivates free radicals which damage cells. Lycopene aids in decreasing the risk of prostate and lung cancer. Lutein helps in maintenance of healthy vision, age related muscular degeneration, asthma, heart disease, lung cancer [46]. Polyphenolic compounds are reported to have great antioxidant ability.

\subsection{Withania somnifera (Ashwagandha)}

Member of family Solanaceae, is recognized as winter cherry. The antioxidant property of plant is chiefly due to phenolic compounds, anthocyanins, and ascorbic acid and other important constituents [47]. Roots, fruits and leaves are rich of polyphenol composition and show high antioxidant activities [48].

\subsection{Zingiber officinale (Ginger)}

Ginger is an herbal supplement which is used in different types of cuisines across the globe. It belongs to a family Zingiberaceae. It was recommended by Indian system that ginger is used as kaya karpam and rejuvenator. It is an herbal medicine having antioxidant, anti-inflammatory, and anticancer which has been consumed as a spice for a long time [49-50]. Antioxidant property shown by ginger is due to phenolic and terpene compound. Fresh ginger has high antioxidant properties as compared to dried ginger because of high moisture content present in fresh ginger. Antioxidant property decreases because gingerol converts into shogaols [51].

\subsection{Azardirachta Indica (Neem)}

Azardirachta Indica, an evergreen tree commonly called as neem in India belongs to Meliaceae family, shows immense medical applications [52]. It is used in Indian subcontinents for cure and prevention of numerous ailments due to presence of antioxidants such as azadirachtin, nimbolinin, nimbin, nimbidin, nimbidol, salanin, and quercetin [53-54].

\subsection{Moringa oleifera (Drumstick Tree)}

This tree basically found in Mexican semiarid and coastal regions. Various diseases can be cured by using Moringa oleifera. This tree shows highest antioxidant properties due to large content of phenolic compounds present in it. This tree contains large number of polyphenols and antioxidants [55]. Phytochemicals present in Moringa oleifera are vanillin, omega fatty acids, carotenoids, ascorbates, tocopherols, beta-sitosterol, moringine, kaempferol, and quercetin and are basically present [56]. The leaves of the tree contain phenolics and flavonoids and shows high antioxidant properties [57].

\subsection{Asparagus racemosus}

It is also known as Satavari, Satawar or Satmuli in Hindi, Shatamuli in Bengali and Satavari in Sanskrit (family Liliaceae). This plant is also called by Sam-Sib or Sam-Roi-Rak in Thailand. The phytochemical assay of the plant extracts show the existence of alkaloids, glycosides, tannins, saponins, steroids, flavonoids and carbohydrates [58]. Due to the presence of saponins and other chemicals it shows biological activities like antioxidant property [59]. Recent study shows that this plant contains ten steroidal saponins [58].

\subsection{Psidium guajava (Guava)}

Psidium guajava (guava) fruit is rich source of antioxidants as well as helpful for controlling diabetes, obesity, high blood pressure and can act as antioxidant [60-61] due to the presence of ascorbic acid [60,62]. In addition Guava also contains Protocatechuic acid, Quercetin, Ferulic acid, Gallic acid and Caffeic acid. Guava contains vitamin C and $\mathrm{A}$ and shows radio protective as well as antioxidant activity [63-64]. Querctin is present in the leaves of guava and it is the most strong and active antioxidant [65-66]. Guava also shows the presence of essential oils, polysaccharides, minerals, vitamins, enzymes, and triterpenoid acid alkaloids, steroids, glycosides, tannins, flavanoids and saponins [67]. Essential oil which is present in leaves contain alpha pinene, beta pinene, isopropyl alcohol, methanol, terpenyl acetate, caryophyllene, longicylene, beta bisabolene and olenolic acid [68]. The bark of the guava tree has $12-30 \%$ of tannin and tannin is also reported to be present in roots also. Guava exhibit antioxidant, antiviral, anticancer and anti- inflammatory properties. Flavonoids present in the guava are beneficial in curing cancerous cells and help to prevent skin aging and anti-plaque activity [69-70]. Guava extract can regulate sugar level in 21 days [71]. Guava also has high antimicrobial property and the extract of leaves can be beneficial in treating cough because of its anti-cough activity [72]. The antimicrobial activity is due to terpinene and pinene in the aqueous extract of plant leaves. Cough, diarrhea, oral ulcers can also be cured due to the bacteriostatic effect on pathogenic bacteria and in some swollen gums wound [73-74].

\subsection{Neolamarckia cadamba (Cadamba)}

The cadamba belongs to the rubiaceae family and is one of the significant medicinal plant. The Cadamba is generally recognized as "kadamba" in Sanskrit and Hindi and as "kodom" in Bengali. It is evergreen tropical tree 
present in different parts of India. It is used for making perfume and Indians strongly believe that god lives inside Cadamba tree.

It has highest number of secondary metabolites (viz., cadambagenic acid, cadamine, quinovic acid, beta-sitosterol, cadambine, etc.) which is used to show pharmacological and biological properties. The phytochemicals are used to cure several diseases and ailments such as diabetes, cardiovascular disorders, cancer and liver damage [75-77]. The Antioxidant properties in the ethanolic extract of the Cadamba tree is used for estimating liver and kidney tissue enzymes using the 2- diphenyl -1-picrylhydazyl (DPPH) assay, the superoxide anion radical scavenging assay, and DNA damage. It was found that the Cadamba possesses potent antioxidant property [78]. Antifungal activity can be shown by Cadamba leaves and the bark extract alcoholic and aqueous extracts of Cadamba fruits have higher antibacterial activity against microorganisms.

A number of phytochemicals and secondary metabolites like saponins, indole and quinoline alkaloids, secoiridoids and triterpenens show antioxidant activity with pharmacological significance from the Cadamba tree [79-82].

\section{PHYTOCHEMICALS AS ANTICANCER}

Cancer is the major reason of death all over the world. Millions of people suffer from cancer and a lot of them lose their lives on battling with this deadly disease. In cancer uncontrolled growth of cells occur which spread across the other parts [83]. These cells undergo mutations and rapidly change their nature and the daughter cells produced are also cancerous. There are different types of cancer but they share some similar characteristics or properties i.e. uncontrolled growth, limitless replication. In this disease apoptosis can be avoided and never encouraged and due to angiogenesis survival of cancer cell takes place. Therefore discoveries and researches were carried out to develop treatment methods and therapies to stop this deadly disease. However many current methods like chemotherapy, radiotherapy [84] etc. when used have side effects on human health too therefore scientists and researchers are heading towards plant for development of herbal medicines that are less toxic as compared to current method.

Plant compounds possessing the properties of inhibiting cell growth, inhibiting proliferation of cancer cells and apoptosis of cell are used for making drugs or used in therapies for treatment of cancer. The drugs derived from plant are natural, readily available and are less toxic compared to synthetic variants. Plant-derived drugs are categorized into four categories based on their different activities and are as follows:

$>$ Methyltransferase Inhibitors

$>$ DNA damage preventive drugs

$>$ Histone deacetylases (HDAC)inhibitors

$>$ Mitotic disruptors [85]

The compounds having sulforaphane, isothiocyanate, isoflavones and pomiferin are categorized as HDAC inhibitors and they hinder the action of carcinogenic proteins e.g. sulforaphane target the important compounds responsible for breast cancer by inhibiting its activity. It decreased the expression of ER, EGFR, HER-2 [86]. Vinca alkaloids, Vincristine, Vinorelbine, Vindesine and Vinflunine bind to $\beta$-tubulin and prevent the working of microtubules [87]. These compounds treat cancer by inducing apoptosis, inducing proliferation, cell cycle arrest etc. A Phytochemical 'Cyanidin glycosides' present in red berries possess both anticancer and antioxidant property through various mechanisms. It is helpful in the dealing Colon and prostate cancer by inducing apoptosis [86].

Phytochemicals are known to possess anticancer properties and are nowadays widely used in the treatment of cancer due to their low toxicity as collated to treatments used nowadays such as chemotherapy, radiotherapy etc.; as these treatments put patients under a lot of stress, are also expensive and also affect their health. Therefore, there is demand for the development of drugs which is less toxic to human health and is less expensive. As from the traditional times plants extract have been used in herbal medicines for treatment therefore plants have been attracting scientific and research interest towards them for the development of alternative treatment and therapies against cancer [87]. As we all know that plants produce $2^{\circ}$ metabolites which are known to possess various phytochemicals which are beneficial in deterrence and cure of diseases. These phytochemical are known to perform various function i.e. they are known to possess antioxidant properties, anticancer properties, antibacterial properties, prevention of free radical formation etc. Therefore keeping in mind today's method new technologies were developed using nanoparticles i.e. using nanoparticles for nano-medicines in which the size of the drug or inserted compound is in the range of "nano" so that it can easily pass into the system and it enhances the anticancer activity of phytochemicals based drug by only targeting the target and not the whole system. This is done so that the effect of drug on the targeted compound is $100 \%$.Plant compounds which are important for survival and "housekeeping" [85] are studied for their growth inhibition activity and induction of apoptosis.

Phytochemicals show anticancer activity through various mechanisms i.e. some polyphenols, flavonoids and brassino steroids show anticancer activity through the process of apoptosis whereas curcumin, thymol, rosmarinic acid, $\beta$ - carotene, quercetin, rutin, allicin, gingerol, epigallocatechin gallate, coumarin and other phytochemicals show their anticancer activity via showing antioxidant behavior.

\subsection{Polyphenols}

Polyphenols present in plants are beneficial to our health as these compounds are natural antioxidants and help us in keeping healthy and preventing against various diseases. There are more than 8,000 different polyphenols [88] 
ICAASET-2021, 20-21 May, 2021, K.R. Mangalam University, Gurugram

International Journal of Technical Research \& Science (Special Issue) ISSN No.:2454-2024 (online)

identified till date and research is further going on. There are different types of polyphenolic compounds like flavonoids, phenolic acids, stilbenes, ligand etc. Out of them gallacatechins, flavonoids, tannins, curcumin possess anticancer properties. Resveratrol is found in green tea. Polyphenols act as natural antioxidant and thereby lessen the risk of cancer. Therefore it is advised to intake polyphenolic compound in person's diet to decrease the risk of disease and ensure health. Polyphenols have the ability to induce apoptosis thereby making it capable to be used as anticancer agent. Polyphenol of the plant curcuma longa i.e. curcumin is an anticancer compound which slows the growth of cancer cells by making several changes in its molecule. Polyphenols show anticancer properties as explained below:

$>$ It carries out apoptosis by mobilization of ' $\mathrm{Cu}$ ' ions which help the DNA to fragment. In the presence of cu ions resveratrol helps in degradation of DNA. [85].

$>$ Polyphenols alter or inhibit the regulations of proteins and other agents necessary for the survival of cancer cells and helps in inhibiting the growth of cancerous cells.

$>$ They possess cytotoxicity and also act as antioxidant i.e. they neutralize harmful free radical and preventing the risk of cancer, diabetes and heart disease.

\subsection{Brassino steroids}

Phytochemicals play a chief role in plant development, résistance and tolerance against disease and pathogens, differentiation of cells [89] etc. This natural compound having anticancer properties is used in cancer therapy. The key point for a compound to be used in anticancer treatment is that the compound should be cytotoxic to cancer cell and cause no harm to normal cell. Brassino steroid fits well for this work and hence is used in cancer treatment. Two natural brassino steroids compounds are being under investigation for their action on cancerous cell. These two brassino steroids compounds namely 28-homocastasterone and 24-epibrassinolide have been used as anticancer agents and have shown proven effects on various cancer cells at micro molar concentration. These compounds are used in treatment of T-lymphoblastic leukemia, cervical carcinoma, lung carcinoma, osteosarcoma cell, breast cancer and prostate cancer.

Brassino steroids offer anticancer mechanism as detailed below:

$>$ They interact with the cell cycle and induce apoptosis in cancerous cell and also induce growth inhibition in cell as cancer cells can't naturally undergo apoptosis and proliferation.

$>$ They can induce cell cycle blockage [85]

$>$ It binds with proteins receptor and inhibits the growth of both type of cancer cell (hormone sensitive and hormone insensitive cancer cells).

\subsection{Flavonoids}

These are the family of polyphenolic compound and are largest family of plant $2^{\circ}$ metabolites. Anthocyanin, flavonols, chalcones and many other flavonoids compounds are known to have anticancer properties. Flavonoids work as anticancer agents as they exert cytotoxicity on cancer cells and also act as antioxidant. The flavonoids present in the fern species dryopteriserythrosora have positive effect on human lung cancer [90] (Lee et al., 2001). Another phytochemical named as 'Apigenin' found in parsley, celery and chamomile is also a flavone which is also effective in lung cancer it works by targeting the leptin and leptin receptor pathway and inducing apoptosis in the cancerous cell. Similarly flavonoids extracted from Erythrina suberosa stem bark and Alpinumi soflavone show cytotoxicity on human blood cancer (Leukemia) [85]. Flavonoids even if present in low concentration show high percentage of anticancer activity. They work as anticancer agents by targeting on main factors causing cancer i.e. inhibition of cancer cell growth, induction of apoptosis, target specificity and cancer cell cytotoxicity.

\subsection{Tinospora Cordifolia (Giloy)}

It belongs to the family of Menisoermaceae and is famous by the name of giloy, heart leaf moonseed plant is a bulky, smooth climbing deciduous shrub [91]. Each part of this plant possesses therapeutic properties though stem and roots are commonly used. They contain alkaloids like cholin, tinosporin, columbin, isocolumbin ,tetrahydopalmatine, and Magnoflorine [92]. The active constituents in T. Cordifolia are columbin, tinosporaside,jatrorhizime,tembeterine,tinocordifolioside, tinosporic acid, tinosporal and tinosporon. In ancient Ayurveda it is commonly known by the name "Amrita "due to its ability to enhance youthfulness, longevity and making us strong and energetic [93].

The uses of various parts of T. Cordifolia are described below:

\subsubsection{Stem}

Used for debility, dyspepsia, fever, urinary disease and jaundice.

\subsubsection{Stem Extract}

treating skin diseases.

\subsubsection{Roots}

Due to the curative properties of roots it allows it to use as antidote in snake bite. 
ICAASET-2021, 20-21 May, 2021, K.R. Mangalam University, Gurugram

International Journal of Technical Research \& Science (Special Issue) ISSN No.:2454-2024 (online)

T. Cordifolia shows immunomodulatory, anti-oxidant, anti-inflammatory, anti-arthritic, anti-allergic properties [94]. T.Cordifolia also shows anticancer activities as it effectively kills HeLa cells in vitro making it capable for its use as anticancer agent.

\subsection{Zingiber officinale Roscoe (Zinger)}

It belongs to family of zingiberaceae. Active constituents present are curcumin, gingerenone A, Gingeols, Shogoals, Zingerone [95]. The health benefits and therapeutic properties of ginger are mainly because of its phenolic compounds such as shogoal and gingerols. After conducting many researches it has been established that ginger possess several biological activities such as antioxidant,anti-inflammatory, anti-microbial,antibacterial,neuroprotective,cardiovascular protective, antiobesity and antinausea etc. as well as anti- cancer against different types of cancer such as breast cancer, cervical cancer, colorectal cancer and prostate cancer [96].

In a vitro study it was observed that a small fraction of dried ginger powder that is rich in polyphenols suppressed the proliferation of colorectal and gastric adenocarcinoma cells [97-98]. The synergistic interaction of different ginger phytochemicals like 6-gingerol, 8-gingerol,10-gingerol and 6- shogoal collectively increase the inhibition and proliferation of PC-3 prostate cancer cells [99].

\subsection{Aloe Barbadensis (Aloe Vera)}

Aloe Vera has shown various therapeutic properties like it has been used for cure of burns, abrasions, dermatitis, constipation, skin problems etc. [100]. Aloe Vera has also shown some effective treatment on cancer. Aloe Vera shows anti-oxidant, anti-inflammatory and anti-cancer properties. The active constituent acemannan is responsible for the immunomodulatory properties of Aloe Vera, whereas another active components anthracene and anthraquinone attribute to its anti-proliferative properties [101].

Aloe emodin an anthraquinone component in Aloe Vera show anticancer properties as it inhibits the proliferation and increased the radio sensitivity of HeLa Cervical Cancer Cells.

$>$ It inhibited cancer cell proliferation and induce cell apoptosis on hepatocellular cancer cell lines

$>$ On breast cancer cell lines, they suppressed proliferation

$>$ On colon cancer cell lines induce apoptosis through activation of Caspase-6 [102]

$>$ Aloe-emodin inhibited cell growth in cancer cell lines of lung cancer, Leukemia and neuroectodermal cancer.

$>$ Another active component Aloin anthraquinonoid component inhibited angiogenesis through suppression of vascular endothelial growth factor (VEGF) [103].

$>$ Aloe Vera is also used in prevention and treatment of skin irritation caused by radiotherapy.

\subsection{Azadirachta indica (Neem)}

Extracts of neem suppress the proliferation and growth of tumor cells through disruption of cell cycle progression. Neem seed oil inhibits HeLa Cervical Cancer cells growth and is known to show proliferation inhibitory effects in prostate cancer cells $[104,105]$. Neem extract interrupts propagation of both androgen dependent and independent prostate cancer cell and estrogen dependent and independent breast cancer cells. Neem derived Gedunin or NLE decreases multiplication of pancreatic or ovarian cancer cells. Extracts from seeds and leaves of neem prompt apoptosis in different types of cancer such as leukemia [106], prostate [107], cervical, colon [108], stomach, breast cancer etc. Different active component present in neem also induces apoptosis. Nimbolide, a component of neem induce apoptosis in breast cancer, prostate cancer, hepatocarcinoma [108], cervical cancer, choriocarcinoma, colon cancer and Leukemia. Azadirachtin, another neem component induces apoptosis in cervical cancer cells.

\subsection{Ziziphus nummularia Wight}

It is known as Bhukamtaka Sukhsharanpala in Sanskrit. It is a thorny small bush or shrub. Different parts of plants such as root, bark, stem, flower and seeds [109] all are used for medicinal purposes. Various components present within the Z. nummularia shows antitumor activity and cytotoxicity on cancer cells such as Betulin and Betulinic acid that are present within the bark and stem show antitumor activity [110]. Betulinic acid glycosides possess cytotoxicity to cancer cells. Another acid i.e.Betulinic acid which is a pentacyclic triterpenoid show selective cytotoxicity against variety of tumor cells [111]. Betulinic acid has also shown to induce apoptosis by generation of reactive oxygen species, activation of protein kinase cascade etc. [112].

\subsection{Curcuma longa Linn (Haldi)}

It is popularly known as turmeric in English or haldi in Hindi is known to possess anticancer and antitumor activities [83]. It is known to inhibit proliferation in a variety of cancer cells. The active ingredient of this plant is curcumin due to which it shows anticancer properties [113]. Curcumin induce apoptosis, inhibits propagation and interferes with cell cycle progression. It shows it's anti-proliferative and apoptosis effects by inhibition of protein tyrosine kinase activity, inhibition of protein kinase C activity, Suppression of C-Myc MRNA Levels and up regulation of B-Cell lymphoma 2 and 2 Mrna expressions [114]. In a study, it was also proven that in prostate cancer cells, curcumin increase apoptosis by enhancing tumor necrosis factor, apoptosis inducing ligand (TRAIL), promoting cleavage [115] and inducing cytochrome $\mathrm{C}$ release. 
ICAASET-2021, 20-21 May, 2021, K.R. Mangalam University, Gurugram

International Journal of Technical Research \& Science (Special Issue) ISSN No.:2454-2024 (online)

\subsection{Withania Somnifera (Ashwagandha)}

Also known as winter cherry or Indian ginseng is an Ayurveda herb, and is used in traditional medicine [116]. It is used to treat conditions such as inflammation, stress, cardiovascular dysfunction, immune response [117] and cancer. It is used to reduce skin carcinogenesis through the enhancement of anti-oxidant enzymes such as Glutathione peroxide and Catalase. In fact the root extract of Ashwagandha prevent cytotoxicity to gastric and skin tumorigenesis. Main phytochemical Withaferin A, present in the roots and leaves of Ashwagandha helps in induction of cell apoptosis, cell cycle arrest, inhibition of angiogenesis and metastasis [118]. The leaf extracts of W. Somnifera show antiproliferative activity on lung, colon, central nervous system and human tumor cells. W. Somnifera is also shown to reduce cancer cell proliferation and increased overall survival time, also shown to reduce the side effect of some chemotherapeutic agents and also enhanced the effectiveness of radiation therapy [119].

\subsection{Andrographis Paniculata (Kalmegh)}

It is commonly known as Bhunimba. Active constituents present in roots and leaves are diterpenes, flavonoids and stigmasterol [120]. The extract of A. paniculata is used in treatment of jaundice and cholestasis and as an antidote for heptotoxins [121]. It shows anti-HIV activity. Andrographolide a major chemical constituent that is present in A. paniculata shows significant anticancer and immune-stimulatory activities by inhibiting cancer cell proliferation without showing any sign of toxicity to subject [122]. Andrographolide possess cytotoxicity against variety of cancer cell [123]. It shows cytotoxicity activity against $\mathrm{k} \beta$ human epidermoid cancer cell, P388 lymphocytic leukemia cells, MCF-7 breast cancer cells and HCT-116 colon cancer cells.

\subsection{Centella asiatica Linn (Brahmi)}

It is recognized as Mandukaparni in Sanskrit and Brahmamanduki in Hindi. This plant also shows potent anticancer properties. The whole part of plants or its leaves are used for medicinal purposes. When the extract of partially purified dose dependent fraction of $\mathrm{C}$. asiatica is administered to human body, they inhibit proliferation of cancer cell lines [124]. There are variety of active constituents that are present in C. asiatica Linn i.e. asiaticoside, hydrocotyline, vallerine, pectic acid, sterol, stigmasterol, flavonoids, thankunosides and ascorbic acid [125]. It is also known to exhibit anti-elastase activity and also act as free radical destroyer. When orally administered provide protection against oxidative damage.

\subsection{Mappia foetida Miers/ Nothapodytes foetida Miers}

Native of tropical countries, the active constituent camptothecin found in wood of $\mathrm{M}$. foetida tree is a chemotherapy drug which is used to treat leukemia [126].The Endophytic fungus that grow on the wood of this plant helps in production of camptothecin. It is known to be effective inhibitor of nucleic acid synthesis in HeLA Cells and L-120 cells. Various other alkaloids and Camptothecin derivatives [127] of M. foetida possess anticancer and anti-tumor activities. A derivative of camptothecin, Irinotecan is active against solid mouse tumors and stops cell proliferation and induces apoptosis in breast carcinoma [128].

\section{REFERENCES}

[1] Wang, H., Khor, To.,Shu, L.,et al.: Plants vs Cancer :a review on natural phytochemicals in preventing and treating cancers ad their druggability. Anticancer Agents Med Chem. 12(10) (2012) 1281-305.

[2] Mendoza, N., Silva, E. M. E.: Introduction to Phytochemicals: Secondary Metabolites from Plants with Active Principles for Pharmacological Importance, Phytochemicals - Source of Antioxidants and Role in Disease. Prevention (2018) 78

[3] Webb, D., Today's dietician, Phytochemicals role in good health, 15 (9) (2013) 70

[4] Nandagoapalan, V., Doss A. and Marimuthu, C.: Phytochemical Analysis of Some Traditional Medicinal Plants. Bioscience Discovery, 2016, 7(1):17-20.

[5] Medawar, E.,Huhn, S.,Villringer witte, A.: The effects of plant-based diets on the body and the brain: a systematic review. Transl.Psychiatry 9(1) (2019) 226.

[6] Cora, J., Dillardand, J.: Bruce German. Journal of the science of food and agriculture 80 (2000) 1744-1756

[7] Gurnani, N., Mehta, D., Gupta, M., Mehta, B. K.: Naturalproducts: source of potential drugs. African Journal of Basic \&Applied Sciences 6 (6) (2014) 171-186.

[8] Winter, A.N., Brenner, M. C., Punessen N.et al.: Comparison of the neuroprotective and anti-inflammatory effects of the anthocyanin metabolites, protocatechuic acid and 4-hydroxybenzoic acid. Oxidative Medicine and Cellular Longevity (2017).

[9] Greenwell, M., Rahman, P. K. S. M.: Medicinal Plants: Their Use in Anticancer Treatment. Int J. pharm Sci Res. 6(10) (2015) 4103-4112.

[10] Shree, T.J., Poompavi, S., Begum, S.M.F.M., Gowrisree, V.,Hemalatha, S.,et al.: Cancer-fighting phytochemicals. Nanomedine Biotherapeutic (2019).

[11] Molyneux, R.J., Lee, S. T., Dale, R., Gardner, Panter, Kip E., James, Lynn F.: Phytochemicals:The good, the bad and the ugly?. Phytochemistry 68 (2007) 2973-2985. 
ICAASET-2021, 20-21 May, 2021, K.R. Mangalam University, Gurugram

International Journal of Technical Research \& Science (Special Issue) ISSN No.:2454-2024 (online)

[12] Hui, C., Qi, X., Qianyong, Z., Xiaoli, P., Jundong, Z., Mantian, M.: Flavonoids, flavonoid subclasses and breast cancer risk: a meta-analysis of epidemiologic studies. PLoS One 8(1) (2013) e54318.

[13] Boeing, H., Bechthold, A., Bub, A., Ellinger, S/, Haller, D. et al.: Critical review: Vegetables and fruit in the prevention of chronic diseases. Eur J Nutr. 51 (2012) 637-663.

[14] Wakai, K., Matsuo, K., Nagata, C. et al.: Lung cancer risk and consumption of vegetables and fruit: an evaluation based on a systematic review of epidemiological evidence from Japan. Jpn J ClinOncol. 41(5) (2011) 693-708.

[15] Foyer, C.H., Noctor, G.: Redox homeostasis and antioxidant signaling: a metabolic interface between stress perception and physiological responses. The Plant Cell 17 (7) (2015) 1866-1875

[16] Stahl, W., Sies, H.: Antioxidant activity of carotenoids. Molecular Aspects of Medicine 24(6) (2003) 345351

[17] Mahajan, S., Tuteja, N.: Cold, salinity and drought stresses: an overview. Archives of Biochemistry and Biophysics 444 (2) (2005) 139-158

[18] Ramakrishna, A., Ravishankar, G. A.,: Infuence of abiotic stress signals on secondary metabolites in plants. Plant Signaling 6 (11) (2011) 1720-1731

[19] YOO, S., Kim, K., Nam, H. Lee.: Discovering health benefits of phytochemicals with integrated analysis of the molecular network, Chemical properties and ethnopharmacological evidence.Nutrients 10(8) (2008)

[20] Lehman, S.: Phytochemicals compounds in plants (2020). https://www.verywellfit.com/phytochemicals,;250723

[21] Shao, Z.M., Shen, Z.Z., Liu, C.H., Sartippour, M.R., Go, V.L., Heber, D., Nguyen, M.: Curcumin exerts multiple suppressive effects on human breast carcinoma cells. Int J Cancer 98(2) (2002) 234-40

[22] Fabricant, D. S., Farnsworth, N. R.: The value of plants used in traditional medicine for drug discovery. Health Perspect 109 (2001) 69-75

[23] Sasidharan, S., Chen, Y., Saravanan, D., Sundram, K.M., Yoga Latha, L.: Extraction, isolation and characterization of bioactive compounds from plants extracts. Afr J Tradit Complement Altern Med. 8(1) (2011) 1-10.

[24] Azwanida, N.N.: A review on the extraction methods use in medicinal plants, principle, strength and limitation. Medicinal and aromatic plants 4(3) (2015)1-6

[25] Huie, C. W.: A review of modern sample-preparation techniques for the extraction and analysis of medicinal plants. Anal Bio Anal Chem 373 (2002) 23-30

[26] Kofi, E., Sea, Solowey, E.: Effect of solvent type on extraction of polyphenols from twenty-three Ivorian plants. J. Animal Plant Sci 5 (2010) 550-558

[27] Altemimi, A., Lakhssassi, N., Baharlouei, A., Watson, D.G., Lightfoot, D.A.: Phytochemicals: Extraction, Isolation, and Identification of Bioactive Compounds from Plant Extracts. Plants (Basel) 6(4) (2017) 42.

[28] Subaki, S.T., Sakamoto, M., Paavilainen, H.: Microwave assisted extraction of phenolic compounds from tea residues under auto hydrolytic condition. Food chem 123 (2000) 1255-1258

[29] Williams, O.J.: Microwave-assisted extraction of capsaicinoids from capsicum fruit. J. Food Biochem 28 (2004) 113-122

[30] Luque-garcia, J.L., Luque, de Castro M.D.: Ultrasound: A Powerful tool for leaching. Tr AC Trends Anal.Chem 22 (2003) 41-47

[31] Barbero, G.F., Liazid, A., Palma, M., Barroso, C.G. Ultrasound-assisted extraction of capsaicinoids from peppers. Talanta 75 (2008) 1332-1337

[32] Dennis, R.A.,Mans and Euridice: Anticancer activity of uncommon medicinal plants from the republic of Suriname:Traditional claims,Preclinical Findings,and Potential Clinical Applicability against cancer . Pharmacognosy - Medicinal Plants: doi:http://dx.doi.org/10.5772/intechopen.82280

[33] Kroon, J.J., Raynie, D.E.: Supercritical fluid extraction.Handbook of sample preparation,Janusz Pawliszyn,New Jersey. John Willey and sons Inc. (2010) 191

[34] Herrero, M., Mendiol, J.A., Cifuentes, A., Ibanez, E.: Supercritical fluid extraction:Recent advances and applications. J. Chromatogr A. (2009) doi:10.1016/j.chroma.2009.12.019

[35] Krishnananda, P. I., Amit, G. D., Dipika, A. P., Mahendra, S. D, Mangesh, P. M., Vaibhav, C. K.: Phytochemicals: extraction methods, identification and detection of bioactive compounds from plant extracts. Journal of Pharmacognosy and Phytochemistry (2011)

[36] Shah Verdi, A. R., Abdolpour, F., Monsef-Esfahani, H. R., Farsam, H. A.: TLC bioautographic assay for the detection of nitrofurantoin resistance reversal Compound. J Chromatogr B 850 (2007) 528-530

[37] Rahalison, L.,Hamburger, M.,Hostettmann, K.,Monod, M.,Frenk, E.A.: Bioautographic agar overlay method for the detection of antifungal compounds from higher plants. Phytochem Anal 2 (1991)199-203

[38] Cannell, R. J. P.: Natural products Isolation. New Jersey: Human press Inc (1998)165-208

[39] Ciccarone, F., Tagliatesta, S., Caiafa, P., Zampieri, M.: DNA methylation dynamics in aging: how far are we from understanding the mechanisms? Mechanisms of Ageing and Development 174 (2018) 3-17

[40] Han, X., Shen, T., Lou, H.: Dietary polyphenols and their biological significance. Int J Mol Sci. 8 (2007) 950-88 
ICAASET-2021, 20-21 May, 2021, K.R. Mangalam University, Gurugram

International Journal of Technical Research \& Science (Special Issue) ISSN No.:2454-2024 (online)

[41] Nordberg, J., Arnér, E. S. J.: Reactive oxygen species, antioxidants, and the mammalian thioredoxin system. Free Radical Biology \& Medicine 31(11) (200) 1287-1312

[42] Brewer, M.: Natural antioxidants: Sources, compounds, mechanisms of action, and potential applications. Comprehensive Reviews in Food Science and Food Safety. 10(4) (2011) 221-247

[43] Miguel, M.G.: Antioxidant and anti-inflammatory activities of essential oils: A short review. Molecules 15(12) (2010) 9252-9287

[44] Harman, D.: Aging: a theory based on free radical and radiation chemistry. Journal of Gerontology 11 (3) (1956) 298-300

[45] Chaitanya, K.V., Pathan, A.K., Mazumdar, S.S., Chakravarthi, G.P., Parine, N., Bobbarala, V.: Role of oxidative stress in human health: An overview. Journal of Pharmacy Research 3 (2010) 1330-1333

[46] Johnson, I.T.: New approaches to the role of diet in the prevention of cancers of the alimentary tract. Mutat Res. 551 (2004) 9-28

[47] Pietta P.: Flavonoides as antioxidant. J Nat Prod 63 (2000) 1035-1042

[48] Alam, N., Hossain, M., Khalil, M.I., Moniruzzaman, M., Sulaiman, S.A., Gan, S.H.: High catechin concentrations detected in Withania somnifera (ashwagandha) by high performance liquid chromatography analysis. BMC Compl Alternative Med 11 (2011) 65

[49] López-Alarcón, C., Denicola, A.: Evaluating the Antioxidant Capacity of Natural Products: A Review on Chemical and Cellular-Based Assays. Analytica Chimica Acta 763 (2013) 1-10

[50] Maulik, N., McFadden, D., Otani, H., Thirunavukkarasu, M., Parinandi, N.L.: Antioxidants in Longevity and Medicine. Oxidative Medicine and Cellular Longevity 2013 (2013) 3

[51] Tang, S.W., Sukari, M.A., Rahmani, M., Lajis, N.H., Ali, A.M.: A New Abietene Diterpene and Other Constituents from Kaempferia angustifolia Rosc. Molecules 16(4) (2011) 3018-3028

[52] Nunes, P. X., Silva, S. F., Guedes, R. J., Almeida, S.: Biological oxidations and antioxidant activity of natural products," in Phytochemicals as Nutraceuticals-Global Approaches to Their Role in Nutrition and Health, InTech (2012)

[53] Govindachari, T. R., Suresh, G., Gopalakrishnan, G., Banumathy, B., Masilamani, S.: Identification of antifungal compounds from the seed oil of Azadirachta indica. Phytoparasitica 26 (1998) 109-116

[54] Rahmani, A. H., Aly, S. M.: Nigella sativa and its active constituents thymoquinone shows pivotal role in the diseases prevention and treatment. Asian Journal of Pharmaceutical and Clinical Research. 8 (1) (2015) $48-53$

[55] Mishra, G., Singh, P., Verma, R. et al.: Traditional uses, phytochemistry and pharmacological properties of Moringa oleifera plant: an overview. Der Pharmacia Lettre 3 (2) (2011)141-164

[56] Mbikay, M.: Therapeutic potential of Moringa oleifera leaves in chronic hyperglycemia and dyslipidemia: a review. Frontiers in Pharmacology 3(24) (2011)12 pages.

[57] Verma, A. R., Vijayakumar, M., Mathela, C. S., Rao, C.V.: In vitro and in vivo antioxidant properties of different fractions of Moringa oleifera leaves. Food and Chemical Toxicology 47 (9) (2009) 2196-2201

[58] Hayes, P.Y., Jahidin, A.H., Lehmann, R., Penman, K., Kitching, W., Voss, J.J.D.: Steroidal saponins from the roots of Asparagus racemosus. Phytochemistry 69 (2008) 796-804.

[59] Bopana Nand Saxena, S.: Asparagus racemosus-ethnopharmacological evaluation and conservation needs. J Ethnopharmacol 110 (2007) 1-15

[60] He, Q., Venant, N.: Antioxidant power of phytochemicals from Psidium guajava leaf. J Zhejiang Univ Sci A 5(6) (2004) 676-83

[61] Musa, K.H., Abdullah, A., Jusoh, K., Subramaniam, V.: Antioxidant activity of pinkflesh guava (Psidium guajava 1.): Effect of extraction techniques and solvents. Food Anal Methods 4 (2011)100-7

[62] Thaipong, K., Boonprakob, U., Cisneros-zevallos, L., Byrne, D.H., Pathom, N.: Hydrophilic and lipophilic antioxidant activities of guava fruits. Southeast Asian J Trop Med Public Health 36 (2005) 254-7.

[63] Jiminez-Escrig, A., Rincon, M., Pulido, R., Saura-Calixto, F.: Guava fruit (Psidium guajava L.) as a new source of antioxidant dietary fiber. J Agric Food Chem 49(11) (2001), 5489-93

[64] Vijayakumar, K., Anand, A.V., Manikandan, R.: In vitro antioxidant activity of Ethanolic extract of Psidium guajava leaves. Int J Res Stud Biosci 3(5) (2015) 145-9

[65] Nantitanon, W., Okonogi, S.: Comparison of antioxidant activity of compounds isolated from guava leaves and a stability study of the most active compound. Drug Discov Ther 6(1) (2012) 38-43

[66] Soman, S., Rauf, A.A., Indira, M., Rajamanickam, C.: Antioxidant and Antiglycative potential of ethyl acetate fraction of Psidium guajava leaf extract in Streptozotocin-induced diabetic rats. Plant Foods Hum Nutr 65 (2010) 386-91

[67] Smith, R.M., Siwatibau, S.: Sesquiterpene hydrocarbons of fijian guavas. Phytochemistry 14(9) (1975) 2013-5

[68] Begum, S., Hassan, S.I., Ali, S.N., Siddiqui, B.S.: Chemical constituents from the leaves of Psidium guajava. Nat Prod Res 18(2) (2004)135-40

[69] Anand, V., Manikandan, K.V., Kumar, S., Pushpa, H.A.: Phytopharmacological overview of Psidium guajava Linn. Phcog J. 8 (2016) 314-20 
ICAASET-2021, 20-21 May, 2021, K.R. Mangalam University, Gurugram

International Journal of Technical Research \& Science (Special Issue) ISSN No.:2454-2024 (online)

[70] Limsong, J., Benjavongkulchai, E., Kuvatanasuchati, J.: Inhibitory effect of some herbal extracts on adherence of Streptococcus mutans. J Ethnopharmacol 92 (2004) 281-9

[71] Rai, P.K., Mehta, S., Watal, G.: Hypolipidaemic \& hepatoprotective effects of Psidium guajava raw fruit peel in experimental diabetes. Indian J Med Res 131 (2010) 820-4

[72] Jaiarj, P., Khoohaswan, P., Wongkrajang, Y., Peungvicha, P., Suriyawong, P., Sumal Saraya, M.L., et al.: Anticough and antimicrobial activities of Psidium guajava Linn. Leaf extract. J Ethnopharmacol 67(2) (1999) 203-12

[73] Rattanachaikunsopon, P., Phumkhachorn, P.: Contents and antibacterial activity of flavonoids extracted from leaves of Psidium guajava. J Med Plants Res 4(5) (2010) 393-6

[74] Dakappa, S.S., Adhikari, R., Timilsina, S.S., Sajjekhan, S.: A review on the medicinal plant Psidium Guajava Linn. (Myrtaceae). J Drug Deliv Ther 3(2) (2013)162-8

[75] Ríos, J.L., Recio, M.C.: Medicinal plants and antimicrobial activity. J Ethnopharmacol 100 (2005) 80-4

[76] Alekhya, V., Deepan, T., Sahoo, S., Dhanaraju, M.D.: Preliminary phytochemical screening and evaluation of in vitro antioxidant activity of Anthocephalous cadamba by using solvent extracts. Eur J Biol Sci 5 (2013) 34-7

[77] Kirana, C., McIntosh, G.H., Record, I.R., Jones, G.P.: Antitumor activity of extract of Zingiber aromaticum and its bioactive sesquiterpenoid zerumbone. Nutr Cancer 45 (2003) 218-25

[78] Chandel, M., Sharma, U., Kumar, N., Singh, B., Kaur, S.: Antioxidant activity and identification of bioactive compounds from leaves of Anthocephalus cadamba by ultra-performance liquid chromatography/electrospray ionization quadrupole time of flight mass spectrometry. Asian Pac J Trop Med 5 (2012) 977-85

[79] Umachigi, S.P., Kumar, G.S., Jayaveera, K., Kishore, K.D., Ashok, K.C., Dhanapal, R.: Antimicrobial, wound healing and antioxidant activities of Anthocephalus Cadamba. Afr J Tradit Complement Altern Med 4 (2007) 481-7.

[80] Alam, M.A., Akter, R., Subhan, N., Rahman, M.M., Majumder, M.M., Nahar, L., Sarker, S.D. Antidiarrhoeal property of the hydroethanolic extract of the flowering tops of Anthocephalus cadamba. Rev Bras Farmacogn 18 (2008)155-9

[81] Banerji, N.: Structure of two new saponins from stem bark of Anthocephalus cadamba MIQ. J Indian Chem Soc 55 (1978) 275-8.

[82] Brown, R.T., Chapple, C.L.: Anthocephalus alkaloids: Cadamine and isocadamine. Tetrahedron Lett. 19 (1976) 629-30

[83] Padmaharish.V, Lakshmi.T: Anticancer activities of medicinal plants-An Update. JPharm Sci \& Res 9(4) (2017) 432-440

[84] Nishida, N., Goel, A.: Genetic and epigenetic signatures in human hepatocellular carcinoma: A systematic review. Curr genomics 2011;12:130

[85] Greenwell, M., Rahman, P.K.S.M.: Medicinal plants:Their use in anticancer treatment. Int J Pharm Sci Res 6(10) (2015) 4103-4112

[86] Singh, S., Sharma, B., Kumar, Ashok.:Lead Phytochemicals for anticancer drug development. Front Plant Sci 7 (2016)

[87] Dennis, R. A. Mans, Euridice.: Anticancer activity of uncommon medicinal plants from the republic of Suriname: Traditional claims,Preclinical Findings and Potential Clinical Applicability against cancer, doi:http://dx.doi.org/10.5772/intechopen.82280

[88] Upadhyay, S., Dixit, M.: Role of polyphenols and other phytochemicals on molecular signaling; Oxidative Medicine and Cellular Longevity 2015 (2015) 15 pages

[89] Fabisiak, J.P., Borisenko, G.G., Kagan, V.E.: Qualitative method of measuring phosphatidylserine externalization during apoptosis using electron paramagnetic reasonance spectroscopy and annexin conjugated iron. Methods Mol Biol 1105 (2014) 613-21

[90] Lee, H.Z., Hsu, S.L., Liu, M.C., Wu, C.H.: Effects and mechanisms of aloeemodin on cell death in human lung squamous cell carcinoma. Eur J Pharmacol 431 (2001) 287-95

[91] Shao, Z.M., Shen, Z.Z., Liu, C.H., Sartippour, M.R., Go, V.L., Heber, D., Nguyen, M.: Curcumin exerts multiple suppressive effects on human breast carcinoma cells. Int J Cancer 98(2) (2002) 234-40

[92] American Cancer Society: Cancer facts and figures, Atlanta: American Cancer Society 2010.

[93] Umadevi, M., Kumar, S.K.P., Bhowmik, D., Duraivel, S.: Traditionally used anticancer herbs in India. J Medicinal Plants Studies 1(3) (2013) 56-74

[94] Sri, P.U., Sree, N.V., Revathi, S., Kumar, Y.U.V.A., Sri, N.D.: Role of herbal medicines in cancer. Int J Pharm Sci Res 1(11) (2010) 7-21

[95] Mao Q. Q., Xu, X.Y., Cao S.Y., Gan, R.Y., Corke, H., Beta, T., Li, H.B.: Bioactive Compounds and Bioactivities of Ginger (Zingiber officinale Roscoe). (2019)

[96] Bray, F., Ferlay, J., Soerjomataram, I., Siegel, R.L., Torre, L.A., Jemal, A.: Global cancer statistics 2018:GLOBOCAN estimates of incidence and mortality worldwide for 36 cancers in 185 countries. CA Cancer. J Clin 68 (2018) 394-424 
ICAASET-2021, 20-21 May, 2021, K.R. Mangalam University, Gurugram

International Journal of Technical Research \& Science (Special Issue) ISSN No.:2454-2024 (online)

[97] Li, F., Li, S., Li, H., Deng, G., Ling, W., Wu, S., Xu, X., Chen, F.: Antiproliferative activity of peels, pulps and Seeds of 61 fruits. J Funct Foods 5 (2013) 1298-1309

[98] Saha, A., Blando, J., Silver, E., Beltran, L., Sessler, J., DiGiovanni, J.: 6-Shogaol from dried ginger inhibits Growth of prostate cancer cells both in vitro and in vivo through inhibition of STAT3 and NF-kappa B Signaling. Cancer Prev Res 7 (2014) 627-638

[99] El-Ashmawy, N.E., Khedr, N.F., El-Bahrawy, H.A., Mansour, H.E.A.: Ginger extract adjuvant to doxorubicin in mammary carcinoma: study of some molecular mechanisms. Eur J Nutr 57 (2018) 981-989

[100] Huang, P.H., Huang, C.Y., Chen, M.C., Lee, Y.T., Yue, C.H., Wang, H.Y., et al.: Emodin and Aloe-Emodin Suppress Breast Cancer Cell Proliferation through ER $\alpha$ Inhibition. Evid Based Complement Alternat Med 2013 (2013) 3761-23.

[101] Feily, A., Namazi, M.R.: Aloe vera in dermatology: a brief review. G Ital Dermatol Venereol 144(1) (2009) $85-91$

[102] Food and Drug Administration. Status of Certain Additional Over-the-Counter Drug Category II and III Active Ingredients. http://www.fda.gov/ohrms/Dockets/98fr/050902a.htm. Accessed November 26, 2014.

[103] HTTPS://nccih.nih.gov/ health/aloevera\#cautions (2011)

[104] Husain, S., Alam, M.A., Jahan, N., Ahmed, S., Kauser, H.S.: Sibr (Aloe Vera) and its therapeutic efficacy described in Unani Medicine: a Review. J Sci Innov Res 3(5) (2014) 545-51

[105] Malik, A., Afaq, S., Shahid, M., Akhtar, K., Assiri, A.: Influence of Ellagic acid on prostate cancer cell proliferation: a caspase dependent Pathway. Asian Pac J Trop Med 4(7) (2011) 550-5

[106] Fabisiak, J.P., Borisenko, G.G., Kagan, V.E.: Quantitative method of Measuring phosphatidylserine externalization during apoptosis using Electron paramagnetic resonance (epr) spectroscopy and Annexin conjugated iron. Methods Mol Biol 1105 (2014) 613-21

[107] Shak, S., Palmer, G., Baehner, F.L., Millward, C., Watson, D., Sledge, G.W., et al.: Molecular characterization of male breast cancer by Standardized quantitative RT-PCR analysis: A large genomic study of 1,447 male breast cancers. J Clin Oncol 27 (2009) 15s

[108] Singh, S., Singh, P.P., Roberts, L.R., Sanchez, W.: Chemopreventive Strategies in hepatocellular carcinoma. Nat Rev Gastroenterol Hepatol 11(1) (2014) 45-54.

[109] Beg, M. A., Teotia, U.V.S., Farooq, S.:In vitro antibacterial and anticancer activity of Ziziphus. Journal of medicinal plants studies 4(5) (2016)230-233

[110] Mukhtar, H.M., Ansari, S.H., Ali, M., Naved, T.: New Compounds from Zizyphus vulgaris. Pharmaceu Biology 42 (2004) 508-511

[111] Sheikh, S., Siddiqui, S., Dhasmana, A., Safia Haque, E., Kamil, M., Lohani, M. et al.: Cissus quadrangularis Linn. Stem Ethanolic extract liberates reactive oxygen species and Induces mitochondria mediated apoptosis in KB cells. Mag 11(44) (2015) 365-374

[112] Bashir, A., Ibrar, K., Shumaila, B., Sadiq, A., Farrukh, H.: Screening of Zizyphus jujuba for antibacterial, phytotoxic and haemagglutination activities. African Journal of Biotechnology 10(13) (2011) 2514-2519

[113] Lakshmi, T., Geetha, R.V.: Glycyrrhiza glabra Linn Commonly known as licorice: A Therapeutic review. Int J Pharm Pharm Sci 3(4) (2011) 20-25

[114] Badria, F.A., Ameen, M., Akl, M.R. Evaluation of cytotoxic Compounds from Calligonum comosum L. growing in Egypt. Z Naturforsch C 62(910) (2007) 656-60

[115] Abdel-Sattar, E.A., Mouneir, S.M., Asaad, G.F., Abdallah, H.M.: Protective effect of Calligonum comosum on haloperidol-induced Oxidative stress in rat. Toxicol Ind Health 30(2) (2014) 147-53

[116] Schauss, A.G., Milholland, R.B.R., Munson, S.: Therapeutic applications of Withania Somnifera (Ashwagandha)- A popular Ayurvedic botanical medicine. Natural Medicine J 1 (1998) 16-19

[117] Widodo, N., Kaur, K., Shrestha, B.G., Takagi, Y., Ishii, T., Wadhwa, R., Kaul, S.C.: Selective Killing of cancer cell by leaf extract of Ashwagandha: Identification of a tumor inhibitory factor and the first molecular insights to its effect. Clinical Cancer Res 13 (2007) 2298-2306

[118] Madhuri, S., Pandey Govind, P.: Efficacy of ProImmu on oestrogen induced uterine Damage in rat. International J Green Pharmacy 2(1) (2007) 23-25

[119] Malik, F., Kumar, A., Bhushn, S., Khan, S., Bhatia, A., Suri, K.A., Quzi, G.N., Singh, J.: Reactive oxygen species generation and mitochondrial dysfunction in the apoptosis cell death Of human myeloid leukemia HL-60 cell by a dietary compound with a ferin A with Concomitant protection by N-acetyl cysteine. Apoptosis 12 (2007) 2115-33

[120] Singh, S., Mehta, A., Baweja, S., Ahirwal, L. and Mehta, P.: Anticancer Activity of Andrographis paniculata and Silybum marianum on Five Human Cancer Cell Lines. Journal of Pharmacology and Toxicology 8 (1) (2013) 42-48

[121] Singh, S., Mehta, A., John, J., Mehta, P.: Anthelmintic potential of Andrographis paniculata, Cajanus cajan and Silybum marianum. PHCOG J. 1(2009) 243-245

[122] Rajagopal, S., Kumar, R.A., Deevi, D.S., Satyanarayana, C., Rajagopalan, R.: Andrographolide, a potential cancer therapeutic agent isolated from Andrographis paniculata. J Exp Ther Oncol 3(3) (2003) 147-58 
ICAASET-2021, 20-21 May, 2021, K.R. Mangalam University, Gurugram

International Journal of Technical Research \& Science (Special Issue) ISSN No.:2454-2024 (online)

[123] Shanmugam, R.K., Nagalingam, M., Ponnanikajamideen, M., Chelladurai M.: Anticancer activity of Andrographis Paniculata leaves extract against neuroblastima (imr-32) and human colon (ht-29) cancer cell line, World Journal of Pharmacy And Pharmaceutical Sciences 4(6) (2015) 1667-1675

[124] Hamid, I. S., Widjaja, N. M. R., Damayanti, R.: Anticancer Activity of Centella asiatica Leaves Extract in Benzo(a)pyrene-Induced Mice. International Journal of Pharmacognosy and Phytochemical Research 8(1) (2016) 80-84

[125] Siegel, R., DeSantis, C., Virgo, K., Stein, K., Mariotto, A., Smith, T., et al.: Cancer treatment and survivorship Statistics. CA: A Cancer Journal for Clinicians 62 (2012) 220-241

[126] Khan, N., Tamboli, E. T., Sharma, V.K., Kumar S.: Phytochemical and pharmacological aspects of Nothapodytes nimmoniana: An overview. Herba Polonica 59(1) (2013) 53-66

[127] Suhas, S., Ramesha, B., Ravikanth, G., Rajesh, P., Vasudeva, R., Ganeshaiah, K. et al.: Chemical profiling Of Nothapodytes nimmoniana populations in the Western Ghats, India for anti-cancer compound. Camptothecin Curr Sci 929(4) (2007) 8-12

[128] Fulzele, D., Satdive, R.: Comparison of techniques for the extraction of the anti-cancer drug camptothecin from Nothapodytes foetida. J Chromatogr 1063(2) (2005)9-13 